\title{
Foam Cell-forming J774 Macrophages Have Markedly Elevated Acyl Coenzyme A:Cholesterol Acyl Transferase Activity Compared with Mouse Peritoneal Macrophages in the Presence of Low Density Lipoprotein (LDL) Despite Similar LDL Receptor Activity
}

\author{
Ira Tabas, George C. Boykow, and Alan R. Tall \\ Department of Medicine, Columbia University College of Physicians and Surgeons, New York 10032
}

\begin{abstract}
Cholesteryl ester (CE) accumulation in arterial wall macrophages (foam cells) is a prominent feature of atherosclerotic lesions. We have previously shown that murine J774 macrophages, unlike mouse peritoneal macrophages, accumulate large amounts of $\mathrm{CE}$ from unmodified low density lipoprotein (LDL). We now report a direct comparison of acyl coenzyme A:cholesterol acyl transferase (ACAT) activity in $\mathbf{J 7 7 4}$ and mouse peritoneal macrophages. Despite similar chloroquine-inhibitable ${ }^{125} \mathrm{I}$-LDL degradation in the two macrophages, ACAT activity in LDL-treated J774 macrophages was 10-30-fold higher than that in LDLtreated mouse peritoneal macrophages. In contrast, acetyl-LDL (matched for degradation with LDL) caused marked stimulation of ACAT activity in mouse peritoneal macrophages. From these data we conclude that $(a)$ in the presence of LDL, J774 macrophages have a highly active ACAT cholesterol esterification pathway compared with mouse peritoneal macrophages; and (b) in mouse peritoneal macrophages, there is a marked difference in the ability of acetyl-LDL vs. LDL to stimulate ACAT even when the lipoproteins are matched for degradation.
\end{abstract}

\section{Introduction}

Cholesteryl ester accumulation in arterial wall macrophages (foam cells) is a prominent feature of atherosclerotic lesions (13). Based primarily on the mouse peritoneal macrophage model, one theory of foam cell formation proposes that macrophages interact not directly with $\mathrm{LDL}^{1}$ but rather with a modified form of LDL (e.g., acetyl-LDL) internalized by a distinct, nonregulatable receptor or "scavenger receptor" (4). The reported inability of mouse peritoneal macrophages to form foam cells in the presence of LDL has not been fully explained but has been thought to be due to a paucity of LDL receptors (5) or to the existence of receptors with a very low affinity for LDL (6) on these cells.

Address correspondence to Dr. Ira Tabas, Department of Medicine, Columbia University, 630 West 168th St., New York, NY 10032.

Received for publication 13 May 1986 and in revised form 20 August 1986.

1. Abbreviations used in this paper: ACAT, acyl coenzyme A:cholesterol acyl transferase; CE, cholesteryl ester; DMEM, Dulbecco's modified Eagle's medium; $\mathrm{HDL}_{3}$, high-density lipoprotein ${ }_{3}$; HMG-CoA, 3-hydroxy3-methylglutaryl-coenzyme A; LDL, low-density lipoprotein; LPDS, lipoprotein-deficient serum.

J. Clin. Invest.

(c) The American Society for Clinical Investigation, Inc.

0021-9738/87/02/0418/09 \$1.00

Volume 79, February 1987, 418-426
As an alternative to this theory, we have been exploring the possibility that foam cells may form by the interaction of native LDL, which has been implicated as the major atherogenic lipoprotein (7), with macrophages in an altered metabolic state $(8,9)$. In particular, we have shown that the J774 macrophage, another murine macrophage, accumulates cholesteryl ester (CE) from native LDL. LDL enters the cell by the apo B,E receptor and is hydrolyzed in lysosomes. The LDL-derived cholesterol is reesterified by acyl coenzyme A:cholesterol acyl transferase (ACAT) (8). However, the $\mathbf{J 7 7 4}$ macrophage LDL receptor and 3-hydroxy-3-methylglutaryl-coenzyme A (HMG-CoA) reductase, the rate-limiting enzyme of cellular cholesterol biosynthesis, are relatively resistant to down regulation by $\mathrm{LDL}$, resulting in receptor-mediated CE storage (8). In addition, we recently found that in ACAT-inhibited $\mathrm{J} 774$ cells, receptor and reductase down regulation were more complete and cholesterol accumulation did not occur (9). These data led us to hypothesize that in the basal state in $\mathbf{J 7 7 4}$ macrophages, LDL-derived cholesterol was diverted away from an intracellular regulatory cholesterol pool by an overactive ACAT cholesterol esterification pathway, leading to diminished down regulation and increased cholesterol esterification (9).

To further explore this hypothesis, we now compare LDLcholesterol metabolism, with an emphasis on cholesterol esterification by ACAT in foam cell-forming $\mathrm{J} 774$ macrophages, with that of mouse peritoneal macrophages, which do not form foam cells in the presence of LDL. This comparison was made possible by the discovery that when mouse peritoneal macrophages are cultured under the appropriate conditions, they express the same degree of LDL receptor activity as $\mathrm{J774}$ macrophages. Thus with equivalent amounts of LDL cholesterol entering the cells, we are able to make a direct comparison of cellular cholesterol metabolism in these two murine macrophages.

\section{Methods}

Materials. Dulbecco's modified Eagle's medium (DMEM), penicillin $(10,000 \mathrm{U} / \mathrm{ml})$, streptomycin $(10,000 \mu \mathrm{g} / \mathrm{ml})$, and glutamine $(200 \mathrm{mM})$ solution were obtained from Gibco Laboratories (Grand Island, NY), and defined fetal bovine serum (lot no. 110451) was obtained from Hyclone Laboratories (Logan, UT). The Falcon tissue culture plasticware used in these studies was purchased from Fisher Scientific Co. (Pittsburgh, PA). Compound 58-035 (3-[decyldimethylsilyl]-N-[2-(4-methylphenyl)1-phenyl-ethyl] propanamide) was generously provided by Sandoz, Inc. (East Hanover, NJ). Stock solutions $(10 \mathrm{mg} / \mathrm{ml})$ were prepared in dimethylsulfoxide and stored at $-20^{\circ} \mathrm{C}$. $\mathrm{Na}^{125}$ (carrier-free in $0.1 \mathrm{~N} \mathrm{NaOH}$ ) was purchased from ICN K \& K Laboratories, Inc. (Plainview, NY), and $\left[1-{ }^{14} \mathrm{C}\right]$ oleic acid, $\left[1-{ }^{14} \mathrm{C}\right]$ oleoyl-CoA, and $\left[1,2,6,7-{ }^{3} \mathrm{H}\right]$ cholesteryl oleate were purchased from New England Nuclear (Boston, MA). Oleic acid, essentially fatty acid-free BSA, egg phosphatidylcholine, and chloroquine were from Sigma Chemical Co. (St. Louis, MO), and cholesterol was obtained from Steraloids, Inc. (Wilton, NH).

Cells. Monolayer cultures of $\mathrm{J} 774$ cells were grown and maintained in DMEM containing $10 \%$ (vol/vol) fetal bovine serum, penicillin (100 
$\mathrm{U} / \mathrm{ml})$, streptomycin $(100 \mu \mathrm{g} / \mathrm{ml})$, and glutamine $(292 \mu \mathrm{g} / \mathrm{ml})$ as described previously (8). For each experiment, the cells were plated in $16 \times 35-$ $\mathrm{mm}$ dishes at a density of $10^{6} \mathrm{cells} / \mathrm{dish}$ and then incubated at $37^{\circ} \mathrm{C}$ in an atmosphere containing $8 \% \mathrm{CO}_{2} / 92 \%$ air.

Monolayer cultures of mouse peritoneal macrophages were prepared as previously described (10). Briefly, peritoneal cells from unstimulated female Swiss Webster mice (25-35 g) were harvested in phosphate-buffered saline (PBS), collected by centrifugation, and plated on $35-\mathrm{mm}$ dishes $\left(5 \times 10^{6}\right.$ cells from 1.5 mice/dish) in DMEM containing $10 \%$ ( vol/vol) fetal calf serum and penicillin, streptomycin, and glutamine as above. After $2 \mathrm{~h}$ of incubation in the $37^{\circ} \mathrm{C}$ incubator, the monolayers were washed with warm PBS to remove nonadherent cells and then incubated overnight in the $10 \%$ fetal calf serum medium unless otherwise indicated.

Lipoproteins. LDL $(d, 1.020-1.063 \mathrm{~g} / \mathrm{ml})$ and high-density lipopro$\operatorname{tein}_{3}\left(\mathrm{HDL}_{3}\right)(d, 1.125-1.21 \mathrm{~g} / \mathrm{ml})$ from fresh human plasma and lipoprotein-deficient serum (LPDS) $(d, 1.215 \mathrm{~g} / \mathrm{ml})$ from fetal bovine serum were isolated by preparative ultracentrifugation. Acetyl-LDL was prepared by reaction with acetic anhydride as described by Goldstein and coworkers (11). ${ }^{125}$ I-labeled LDL and acetyl-LDL were prepared by the iodine monochloride method (12). LDL labeled with $\left[{ }^{3} \mathrm{H}\right] \mathrm{CE}$ was prepared by incubating $\left[{ }^{3} \mathrm{H}\right] \mathrm{CE}$-labeled $\mathrm{HDL}_{3}$ (see ref. $13 ; 97 \%$ of the radioactivity was present in $\mathrm{CE}$ and $3 \%$ in free cholesterol) with $\mathrm{LDL}$ in the presence of CE transfer protein, purified $\sim 400$-fold through the carboxymethylcellulose chromatography step as described previously [14]). Specifically, $10^{7} \mathrm{cpm}$ of $\left[{ }^{3} \mathrm{H}\right] \mathrm{CE}-$ labeled $\mathrm{HDL}_{3}(1.6 \mathrm{mg} \mathrm{CE})$ plus LDL (16 mg CE) plus $C E$ transfer protein $(\sim 450 \mu \mathrm{g}$ of the partially purified protein) were incubated in a total volume of $2 \mathrm{cc}$ for $20 \mathrm{~h}$ at $37^{\circ} \mathrm{C}$. The labeled LDL was isolated by ultracentrifugation at $1.063 \mathrm{~g} / \mathrm{ml}$, dialyzed against 150

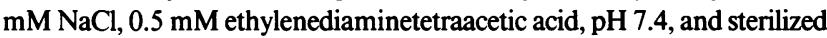
by filtration $(0.2 \mu \mathrm{M})$. The final preparation of $\left[{ }^{3} \mathrm{H}\right] \mathrm{CE}$-labeled LDL contained $99 \%$ of the radioactivity in $\mathrm{CE}$ and had a specific activity of $447 \mathrm{cpm} / \mu \mathrm{g} \mathrm{CE}$.

Lipid mass assays. After incubation in the indicated media, cells were washed and collected as described (8). After an aliquot was removed for protein determination (15), the cells were lipid-extracted by the method of Folch et al. (16). When the cell medium was assayed, lipid extraction was by the method of Bligh and Dyer (17). The lipid extracts were then analyzed for free and total cholesterol content by gas-liquid chromatography (18). $\beta$-sitosterol served as an internal standard to correct for losses during the extraction procedure.

${ }^{125}$ I-lipoprotein degradation assay. Monolayers of $\mathrm{J} 774$ cells and mouse peritoneal macrophages were preincubated according to the individual figure legends and then incubated for $5 \mathrm{~h}$ (unless otherwise noted) at $37^{\circ} \mathrm{C}$ with the indicated concentrations of ${ }^{125} \mathrm{I}-\mathrm{LDL}$ or ${ }^{125} \mathrm{I}$ acetyl-LDL ( $100 \mathrm{cpm} / \mathrm{ng}$ ) alone or with $500 \mu \mathrm{g} / \mathrm{ml}$ excess of the respective unlabeled lipoprotein. The media was then assayed for ${ }^{125}$ I-lipoprotein degradation as previously described (8). Specific degradation was calculated by subtracting the nonspecific value (assay in the presence of excess unlabeled lipoprotein) from the total value (assay with ${ }^{125}$ I-lipoprotein alone). ${ }^{2}$

Whole cell cholesterol esterification assay. Monolayers of J774 and mouse peritoneal macrophages were preincubated for $20 \mathrm{~h}$ in DME/ $10 \%$ LPDS and then incubated for $7 \mathrm{~h}$ (unless otherwise noted) in DMEM containing 10\% LPDS in the absence or presence of added lipoproteins. During the last $2 \mathrm{~h}$ of the $7-\mathrm{h}$ incubation, the cells were pulsed at $37^{\circ} \mathrm{C}$ with $\left[{ }^{14} \mathrm{C}\right]$ oleate-albumin complex $\left(10 \mathrm{mM}\left[{ }^{14} \mathrm{C}\right]\right.$ oleate- $1.2 \mathrm{mg} / \mathrm{ml}$ bovine serum albumin (BSA), $5,000 \mathrm{cpm} / \mathrm{nmol}$ of $\left[{ }^{14} \mathrm{C}\right]$ oleate), and the lipid extracts of these cells were assayed for cholesteryl $\left[{ }^{14} \mathrm{C}\right]$ )leate (and other $\left[{ }^{14} \mathrm{C}\right]$ oleate-containing lipids when indicated) according to published

2. The "specific" values shown for ${ }^{125} \mathrm{I}-\mathrm{LDL}$ degradation at high ${ }^{125} \mathrm{I}$ LDL concentrations $(\geq 100 \mu \mathrm{g} / \mathrm{ml})$ may be less than the true specific value because the maximal amount of excess unlabeled LDL used in this study was limited to $1 \mathrm{mg} / \mathrm{ml}$ ( $\leq 10$-fold excess for high ${ }^{125} \mathrm{I}$-LDL concentrations). Larger amounts of unlabeled LDL could not be used due to cell toxicity. procedures (12). The incorporation of $\left[{ }^{14} \mathrm{C}\right]$ oleate into $\mathrm{CE}$ was linear up to at least a $3-\mathrm{h}\left[{ }^{14} \mathrm{C}\right]$ oleate pulse time.

Cellular metabolism of $\left[{ }^{3} \mathrm{H}\right] \mathrm{CE}$-labeled LDL. Monolayers of $\mathrm{J} 774$ and mouse peritoneal macrophages were incubated with $\left[{ }^{3} \mathrm{H}\right] \mathrm{CE}$-labeled LDL as described in the legend to Table I. The medium was lipid extracted by the method of Bligh and Dyer (17) and analyzed for free $\left[{ }^{3} \mathrm{H}\right]$ cholesterol content by thin-layer chromatography (hexanes/diethyl ether/glacial acetic acid, 70:30:1). The cells were lipid extracted by the method of Folch et al. (16) and analyzed for $\left[{ }^{3} \mathrm{H}\right] \mathrm{CE}$ and free $\left[{ }^{3} \mathrm{H}\right]$ cholesterol by the above thin-layer chromatography system. $\left[{ }^{14} \mathrm{C}\right]$ cholesterol served as an internal standard to correct for losses during the extraction procedure.

Microsomal ACAT assay. A modification of the method of Brown et al. (19) was used. Monolayers of J774 and mouse peritoneal macrophages (three confluent 100 -mm dishes) were preincubated for $20 \mathrm{~h}$ with DMEM/10\% LPDS and treated for $5 \mathrm{~h}$ with DMEM/LPDS alone or containing LDL or acetyl-LDL as indicated. The monolayers were then washed three times with ice-cold PBS, and the cells were scraped with a rubber policeman (without noticeable cell disruption) into PBS ( $5 \mathrm{cc}$ per dish) and collected by centrifugation. After washing once with $10 \mathrm{cc}$ PBS, the cell pellets were stored at $-70^{\circ} \mathrm{C}$ until use the next day. For preparation of microsomes, the cell pellets were thawed in $2 \mathrm{cc}$ of 20

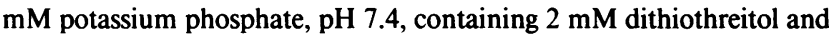
homogenized at $4^{\circ} \mathrm{C}$ with 60 strokes of a Dounce homogenizer with a type A (tight-fitting) pestle. The cell homogenate was then depleted of whole cells and nuclei by centrifugation at $800 \mathrm{~g}$ for $10 \mathrm{~min}$. The postnuclear supernate was then centrifuged at $100,000 \mathrm{~g}$ for $1 \mathrm{~h}$, and the microsomal pellet was resuspended in $0.5 \mathrm{cc}$ of $0.1 \mathrm{M}$ potassium phos-

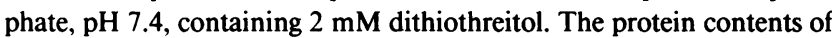
the postnuclear supernate, $100,000 \mathrm{~g}$ supernate, and $100,000 \mathrm{~g}$ pellet (microsomes) were, respectively, 4.74, 2.16 , and $1.87 \mathrm{mg}$ for J774 macrophages and $6.00,3.34$, and $1.83 \mathrm{mg}$ for mouse peritoneal macrophages.

For the ACAT assay, aliquots (50 $\mu \mathrm{g}$ of protein) of the cell fractions were incubated in duplicate for $15 \mathrm{~min}$ (within the linear range of the reaction for both protein and time) at $37^{\circ} \mathrm{C}$ in a final volume of $0.2 \mathrm{cc}$ containing $100 \mathrm{mM}$ potassium phosphate, $\mathrm{pH} 7.4,2 \mathrm{mM}$ dithiothreitol, $1.2 \mathrm{mg}$ of fatty acid-free BSA, and, to start the reaction, $0.1 \mathrm{mM}$ $\left[1-{ }^{14} \mathrm{C}\right]$ oleoyl-CoA $(15 \mathrm{cpm} / \mathrm{pmol})$. The reaction was stopped and assayed for cholesteryl $\left[{ }^{14} \mathrm{C}\right]$ oleate radioactivity as described (19). Control reactions

Table I. Chloroquine Inhibition of ${ }^{125}$ I-LDL Degradation by LPDS-preincubated Mouse Peritoneal Macrophages

\begin{tabular}{|c|c|c|c|}
\hline \multirow[b]{2}{*}{$\begin{array}{l}\text { Concentration } \\
\text { of }{ }^{125} \mathrm{I} \text {-LDL }\end{array}$} & \multirow[b]{2}{*}{$\begin{array}{l}100 \mu \mathrm{M} \\
\text { chloroquine }\end{array}$} & \multicolumn{2}{|c|}{${ }^{125}$ I-LDL degradation } \\
\hline & & Specific & Total \\
\hline$\mu g / m l$ & & $\mu \mathrm{g} / \mathrm{mg}$ cell protel & \\
\hline 10 & - & $1.00^{*}$ & $1.19^{*}$ \\
\hline 10 & + & $0.05(92 \%)^{\ddagger}$ & $0.09(95 \%)$ \\
\hline 200 & - & 4.45 & 6.35 \\
\hline 200 & + & $0.38(86 \%)$ & $0.91(91 \%)$ \\
\hline
\end{tabular}

Monolayers of mouse peritoneal macrophages (preincubated with DMEM/10\% LPDS for $20 \mathrm{~h}$ ) were incubated for $5 \mathrm{~h}$ with DMEM/ $0.1 \%$ BSA containing either $10 \mu \mathrm{g} / \mathrm{ml}$ or $200 \mu \mathrm{g} / \mathrm{ml}{ }^{125} \mathrm{I}-\mathrm{LDL}$ in the absence or presence of either $0.5 \mathrm{mg} / \mathrm{ml}$ or $1 \mathrm{mg} / \mathrm{ml}$ unlabeled LDL, respectively. Parallel dishes were preincubated for $30 \mathrm{~min}$ in medium containing $100 \mu \mathrm{M}$ chloroquine and then were incubated for $5 \mathrm{~h}$ with the ${ }^{125} \mathrm{I}-\mathrm{LDL} \pm$ excess unlabeled LDL (as above) plus $100 \mu \mathrm{M}$ chloroquine. The chloroquine-treated cells appeared fully viable. The medium was then assayed for total and specific ${ }^{2}{ }^{125}$ I-LDL degradation as described under Methods.

* Average of duplicates that varied by $<10 \%$.

${ }^{\ddagger}$ Number in parentheses is percent of ${ }^{125}$ I-LDL degradation inhibited by chloroquine. 
in which the protein had been omitted and 0-time incubations contained no detectable cholesteryl $\left[{ }^{14} \mathrm{C}\right]$ oleate.

In certain reactions, exogenous cholesterol was added in the form of liposomes. Briefly, $10 \mathrm{mg}$ of cholesterol and $19.5 \mathrm{mg}$ of egg phosphatidylcholine were cosonicated in $5 \mathrm{cc}$ of $0.1 \mathrm{M}$ potassium phosphate, $\mathrm{pH}$ 7.4 , containing $2 \mathrm{mM}$ dithiothreitol. Varying amounts (50-100 $\mu \mathrm{l})$ of the translucent solution were added to the reaction mixture at the start of the 15-min incubation.

\section{Results}

$L D L$ receptor activity in mouse peritoneal macrophages. Freshly isolated mouse peritoneal macrophages degrade only very small amounts of ${ }^{125} \mathrm{I}-\mathrm{LDL}$ as reported previously $(5,11)$ and as displayed in Fig. 1 (solid bar). However, when the cells were incubated for $48 \mathrm{~h}$ in medium containing LPDS, which has been shown to up-regulate the fibroblast LDL receptor (7), ${ }^{125} \mathrm{I}-\mathrm{LDL}$ degradation increased $\sim$ seven-fold (Fig. 1). Both total and specific degradation were inhibited $\sim 90 \%$ by treatment of the cells with $100 \mu \mathrm{M}$ chloroquine (Table I), indicating lysosomal hydrolysis of the LDL. Inclusion of butylated hydroxytoluene (20 $\mu \mathrm{M})$ in the incubation of ${ }^{125} \mathrm{I}-\mathrm{LDL}$ with LPDS-preincubated mouse peritoneal macrophages did not decrease the amount of lipoprotein degradation, indicating that the augmented degradation of ${ }^{125}$ I-LDL in these cells was not due to lipoprotein oxidation and subsequent uptake by the scavenger receptor as has been described in other systems (20). That this up-regulation of LDL receptor activity was related to the incubation with LPDS rather than to the two extra days of cell culture was demonstrated by showing that mouse peritoneal macrophages incubated for $48 \mathrm{~h}$ in medium containing $20 \%$ fetal bovine serum instead of LPDS degraded ${ }^{125} \mathrm{I}-\mathrm{LDL}$ only slightly more than fresh mouse peritoneal macrophages (Fig. 1). Thus, when mouse peritoneal macrophages are preincubated in LPDS-containing medium, the cells acquire the ability to degrade substantial amounts of ${ }^{125}$ I-LDL.

To directly compare LDL receptor activity in mouse peritoneal and J774 macrophages, cells preincubated in LPDS-containing medium were incubated with increasing amounts of ${ }^{125} \mathrm{I}$ LDL for $5 \mathrm{~h}$ (Fig. $2 A$ ) or with $10 \mu \mathrm{g} / \mathrm{ml}^{125} \mathrm{I}-\mathrm{LDL}$ for increasing time periods (Fig. $2 B$ ) and assayed for total and specific ${ }^{125} \mathrm{I}$ -

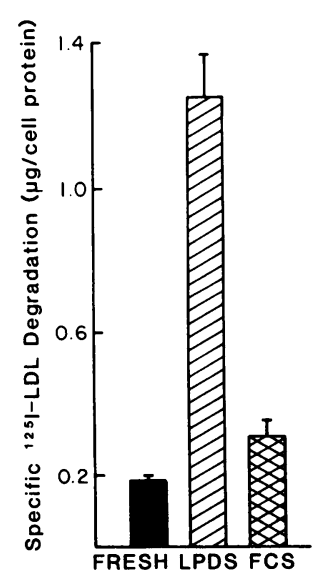

Figure 1. Specific ${ }^{125} \mathrm{I}-\mathrm{LDL}$ degradation by control and LPDS-preincubated mouse peritoneal macrophages. Mouse peritoneal macrophages were isolated by peritoneal lavage and allowed to adhere for $2 \mathrm{~h}$ to 35-mm tissue culture dishes in the presence of DMEM containing 20\% FCS as described in Methods. The monolayers were then washed three times with warm PBS to remove nonadherent cells. Some of the monolayers (Fresh) were then incubated at $37^{\circ} \mathrm{C}$ for $5 \mathrm{~h}$ with $1 \mathrm{ml} \mathrm{DMEM/}$ $0.1 \%$ BSA containing $10 \mu \mathrm{g} / \mathrm{ml}{ }^{125} \mathrm{I}$ $\mathrm{LDL} \pm 500 \mu \mathrm{g} / \mathrm{ml}$ unlabeled $\mathrm{LDL}$ and assayed for specific ${ }^{125}$ I-LDL degradation as described in Methods. The remaining monolayers were incubated for $48 \mathrm{~h}$ with $1.5 \mathrm{ml}$ of DMEM containing either 10\% LPDS (LPDS) or $10 \%$ fetal calf serum $(F C S)$ and then assayed for specific ${ }^{125}$ I-LDL degradation as above. The total ${ }^{125} \mathrm{I}-\mathrm{LDL}$ degradation values for the Fresh, LPDS, and $F C S$ cell were, respectively, $0.33 \pm 0.01,1.55 \pm 0.11$, and $0.54 \pm 0.04$ $\mu \mathrm{g} / \mathrm{mg}$ cell protein. Values shown are means of triplicates $\pm \mathrm{SE}$.
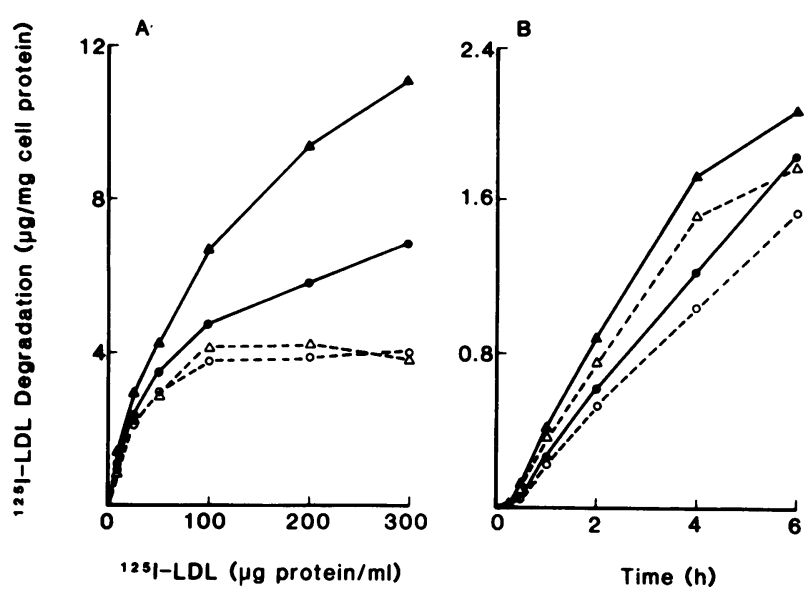

Figure 2. Concentration and time dependence of ${ }^{125} \mathrm{I}-\mathrm{LDL}$ degradation by LPDS-preincubated J774 and mouse peritoneal macrophages. Monolayers of $\mathrm{J} 774$ macrophages (circles) and mouse peritoneal macrophages (triangles) were preincubated for $20 \mathrm{~h}$ in $1.5 \mathrm{ml} \mathrm{DMEM}$ containing 10\% LPDS. The cells were then incubated with $1 \mathrm{ml}$ of DMEM/0.1\% BSA containing either the indicated concentrations of ${ }^{125} \mathrm{I}-\mathrm{LDL}\left( \pm 1 \mathrm{mg} / \mathrm{ml}\right.$ unlabeled LDL) for $5 \mathrm{~h}(A)$ or $10 \mu \mathrm{g} / \mathrm{ml}{ }^{125} \mathrm{I}-$ $\mathrm{LDL}$ ( $\pm 500 \mu \mathrm{g} / \mathrm{ml}$ unlabeled LDL) for the indicated time periods $(B)$. The cells were then assayed for total (solid symbols) and specific ${ }^{2}$ (open symbols) ${ }^{125} \mathrm{I}-\mathrm{LDL}$ degradation as described under Methods.

LDL degradation. The ${ }^{125}$ I-LDL concentration data (Fig. $2 A$ ) show that specific degradation (open symbols) was similar for both cell types at all concentrations tested. ${ }^{2}$ Total degradation (solid symbols) was also similar for the two cell types at lower ${ }^{125}$ I-LDL concentrations, and at higher concentrations total degradation was actually greater for mouse peritoneal macrophages (solid triangles) than for $\mathrm{J} 774$ macrophages (solid circles). The time course data (Fig. 2 B), done at an LDL concentration of $10 \mu \mathrm{g} / \mathrm{ml}$, showed similarity of both total and specific ${ }^{125} \mathrm{I}-\mathrm{LDL}$ degradation for the two cell types up to at least $6 \mathrm{~h}$ of incubation. Thus, when the two murine macrophages are incubated with similar amounts of LDL for these time periods, mouse peritoneal macrophages degrade at least as much LDL as J774 macrophages, indicating that at least as much LDL cholesterol reaches the lysosomal compartment of the mouse peritoneal macrophage as in the $\mathbf{J 7 7 4}$ macrophage.

CE mass accumulation in LPDS-preincubated J774 and mouse peritoneal macrophages. Because LPDS-preincubated mouse peritoneal macrophages initially (i.e., at least up to $6 \mathrm{~h}$ ) degrade at least as much LDL as J774 macrophages, we wanted to compare directly the ability of these two cell types to accumulate LDL-derived CE under these conditions. Therefore, LPDS-preincubated mouse peritoneal and J774 macrophages were incubated with increasing amounts of LDL for $24 \mathrm{~h}$ and then assayed for cholesterol content (Fig. 3). At all LDL concentrations tested, J774 macrophages (solid symbols) accumulated significantly more $\mathrm{CE}$ than mouse peritoneal macrophages (open symbols). This difference in CE accumulation in the two murine macrophages, despite the same initial amount of LDL cholesterol uptake, could be explained by two possibilities: (a) J774 macrophages esterify the internalized LDL-cholesterol more efficiently than mouse peritoneal macrophages (a possibility consistent with our previous data with ACAT-inhibited J774 macrophages; see Introduction and ref. 8); and/or (b) mouse peritoneal macrophages internalize less LDL over a 24-h period (note that the degradation experiments in Fig. 2 were performed 


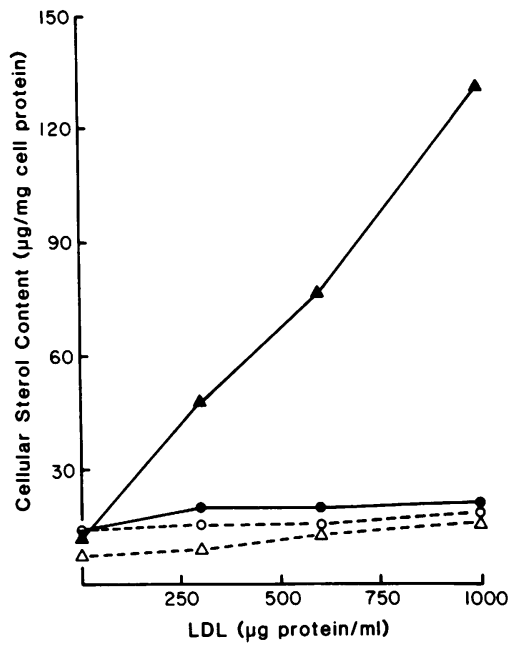

in $6 \mathrm{~h}$ or less) due to relatively efficient LDL receptor downregulation in comparison with $\mathrm{J} 774$ macrophages, which we have previously shown to have diminished LDL receptor down-regulation (8).

Cholesterol esterification in LPDS-preincubated J774 and mouse peritoneal macrophages. To directly test the possibility that J774 macrophages more actively esterify cholesterol in the presence of LDL than do mouse peritoneal macrophages, we took advantage of the above findings that, over an incubation period of at least $6 \mathrm{~h}$, LPDS-preincubated mouse peritoneal macrophages degrade at least as much LDL as $\mathrm{J} 774$ macrophages (Fig. 2). Thus, with comparable amounts of LDL cholesterol reaching the lysosomal compartments of the two cells, we could meaningfully compare their LDL-stimulated cholesterol esterification rates. Therefore, LPDS-preincubated J774 and mouse peritoneal macrophages were incubated with increasing amounts of $\mathrm{LDL}$ for $5 \mathrm{~h}$, pulsed with $\left[{ }^{14} \mathrm{C}\right]$ oleate for $2 \mathrm{~h}$ (the reaction is linear up to at least a 3-h pulse), and then assayed for cholesteryl $\left[{ }^{14} \mathrm{C}\right]$ oleate radioactivity (Fig. $4 \mathrm{~A}$ ). Cholesterol esterification in $\mathrm{J} 774$ cells was markedly greater than that in mouse peritoneal macrophages in both LPDS-treated cells treated with a wide range of LDL concentrations. In addition, the marked difference in LDL-induced cholesterol esterification in the two cell types was evident when the cells were pulsed with $\left[{ }^{14} \mathrm{C}\right]$ oleate after exposure to LDL for different times (Fig. $4 \mathrm{~B}$ ). In contrast, incorporation of $\left[{ }^{14} \mathrm{C}\right]$ oleate into other cellular lipids (Fig. 5) was either similar in the two cell types or actually greater (in the case of phospholipids plus monoglycerides) in the mouse peritoneal macrophages. Thus, the marked differences in cholesterol esterification in the two cell types is not due to an overall difference in cellular lipid fatty acylation. In addition, the data in Fig. 5 imply that the cholesterol esterification differences observed by the $\left[{ }^{14} \mathrm{C}\right]$ oleate pulse assay are not due to differences in $\left[{ }^{14} \mathrm{C}\right]$ oleate uptake or in unlabeled intracellular oleate pools in the two cell types. Therefore, cholesterol esterification in LDL-treated J774 macrophages is much greater than that in LDL-treated mouse peritoneal macrophages, despite the fact that mouse peritoneal macrophages degrade at least as much LDL as J774 macrophages.

We next undertook a series of experiments with $\left[{ }^{3} \mathrm{H}\right] \mathrm{CE}$ labeled LDL with the following objectives in mind: $(a)$ to prove
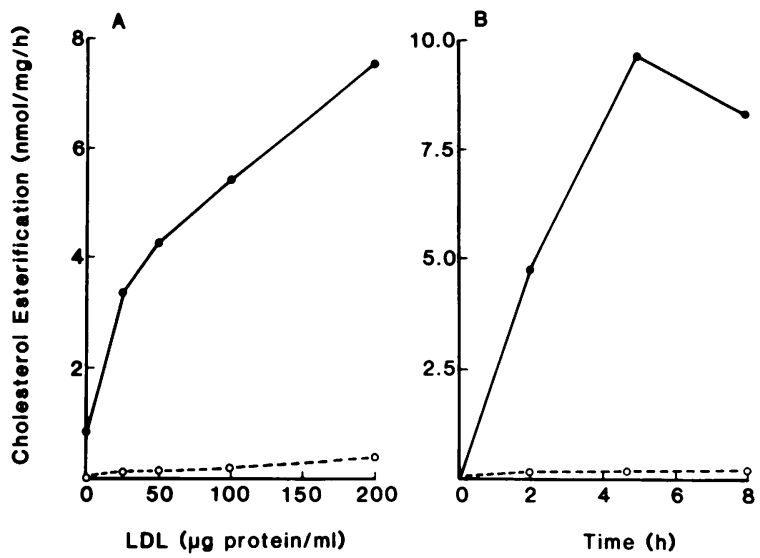

Figure 4. Concentration and time dependence of cholesterol esterification by LPDS-preincubated $\mathrm{J} 774$ and mouse peritoneal macrophages in the presence of LDL. J774 macrophages (solid circle) and mouse peritoneal macrophages (open circle) were preincubated for $20 \mathrm{~h}$ in DMEM/10\% LPDS. For the concentration dependence study $(A)$, the cells were incubated for $7 \mathrm{~h}$ in DMEM/10\% LPDS containing the indicated concentrations of LDL. During the last $2 \mathrm{~h}$ of this 7 - $\mathrm{h}$ incubation, the cells received $\left[{ }^{14} \mathrm{C}\right]$ oleate-albumin complex, and at the end of the $7-\mathrm{h}$ incubation, the cells were assayed for cholesteryl $\left[{ }^{14} \mathrm{C}\right]$ oleate content as described in Methods. For the time dependence study $(B)$, cells were incubated with DMEM/10\% LPDS containing LDL $(117 \mu \mathrm{g}$ protein $/ \mathrm{ml}$ ) for the indicated time periods. During the last $2 \mathrm{~h}$ of these indicated time periods, the cells received $\left[{ }^{14} \mathrm{C}\right]$ oleate-albumin complex and were then assayed for cholesterol esterification as above.

that the substantial amount of LDL degraded by LPDS-preincubated mouse peritoneal macrophages (as assayed by protein degradation) resulted in the hydrolysis of LDL-CE to free cholesterol; $(b)$ to determine if the differences in cholesterol esterification seen in the two macrophages in the presence of LDL involved esterification of cholesterol actually derived from LDL

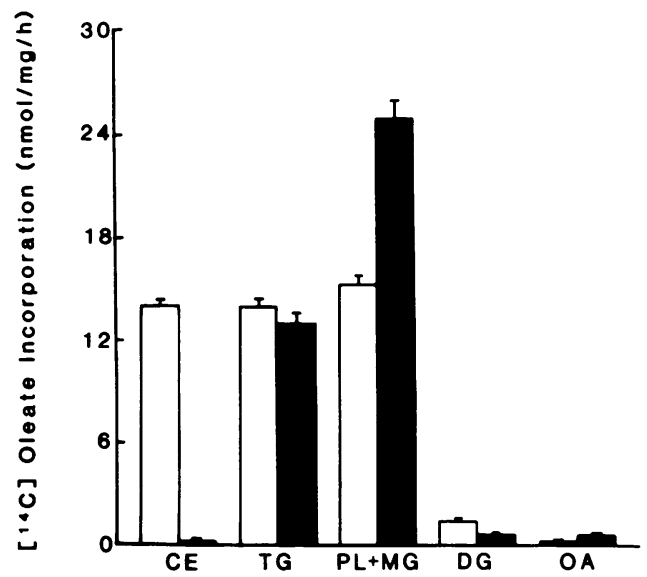

Figure 5. Incorporation of $\left[{ }^{14} \mathrm{C}\right]$ oleate into cellular lipids of LPDSpreincubated $\mathbf{J} 774$ and mouse peritoneal macrophages. J774 macrophages (open bars) and mouse peritoneal macrophages (solid bars) were preincubated for $20 \mathrm{~h}$ in DMEM/10\% LPDS and then incubated for $7 \mathrm{~h}$ in DMEM/10\% LPDS containing $300 \mu \mathrm{g} / \mathrm{ml} \mathrm{LDL}$. During the last $2 \mathrm{~h}$ of the $7-\mathrm{h}$ incubation period, the cells received $\left[{ }^{14} \mathrm{C}\right]$ oleate-albumin complex. At the end of the 7-h incubation period, the cells were assayed for $\left[{ }^{14} \mathrm{C}\right]$ oleate-containing lipids $(\mathrm{CE}$, cholesteryl ester; TG, triglyceride; PL + MG, phospholipid plus monoglyceride: DG, diglyceride; OA, oleic acid) as described under Methods. Values shown are means of triplicates \pm SE. 
itself; and (c) to determine the fate in LPDS-preincubated mouse peritoneal macrophages of the internalized LDL-cholesterol that is neither esterified (Fig. 4) nor accumulated as free cholesterol (Fig. 3). Therefore, J774 and mouse peritoneal macrophages were incubated with [ $\left.{ }^{3} \mathrm{H}\right] \mathrm{CE}-$ labeled LDL $(217 \mu \mathrm{g} \mathrm{CE} / \mathrm{ml}, 110$ $\mu \mathrm{g}$ protein $/ \mathrm{ml}$ ) for $8 \mathrm{~h}$, and then the cells were assayed for free $\left[{ }^{3} \mathrm{H}\right]$ cholesterol and $\left[{ }^{3} \mathrm{H}\right] \mathrm{CE}$ content and the medium for free $\left[{ }^{3} \mathrm{H}\right]$ cholesterol content (Table II). The total amount of LDLcholesterol metabolized by the two cells (sum of cellular $\left[{ }^{3} \mathrm{H}\right] \mathrm{CE}$, cellular free $\left[{ }^{3} \mathrm{H}\right]$ cholesterol, and medium free $\left[{ }^{3} \mathrm{H}\right]$ cholesterol) was similar, corroborating the data showing similar amounts of ${ }^{125}$ I-LDL degradation by the two macrophages (Fig. 2). The finding that $97 \%$ of the LDL-cholesterol metabolized by mouse peritoneal macrophages was in the form of free cholesterol (cellular free cholesterol + medium free cholesterol) establishes that the LDL internalized by these cells results in LDL-CE hydrolysis to free cholesterol. Most importantly, the amount of LDL-derived cholesterol in cellular CE was more than 10-fold higher in the J774 macrophage; we have previously shown that the CE that accumulates in LDL-treated $\mathbf{J 7 7 4}$ cells represents hydrolyzed and ACAT-reesterified cholesterol rather than simply the original unhydrolyzed LDL-CE (8). Thus, over a time period when LDL degradation by the two macrophages was similar (Fig. 2), the amount of reesterified cholesterol derived from LDL was markedly higher in the $\mathrm{J} 774$ macrophage, corroborating the previous $\left[{ }^{14} \mathrm{C}\right]$ oleate pulse data (Figs. 4 and 5).

The data in Table II also demonstrate that a much greater proportion of LDL-cholesterol is excreted by mouse peritoneal macrophages than by $\mathbf{J 7 7 4}$ macrohages. We therefore considered the possibility that overactive LDL-derived cholesterol excretion by mouse peritoneal macrophages might cause the low LDLinduced cholesterol esterification activity in these cells by di-

Table II. Metabolism of $\left[{ }^{3} \mathrm{H}\right] \mathrm{CE}$-labeled $\mathrm{LDL}$ by $J 774$ and Mouse Peritoneal Macrophages

\begin{tabular}{lllll}
\hline & & \multicolumn{2}{l}{ Free $\left[{ }^{3} \mathrm{H}\right]$ cholesterol } & \\
\cline { 3 - 4 } Macrophage & $\begin{array}{l}\text { Cellular } \\
{\left[{ }^{3} \mathrm{H}\right] \mathrm{CE}}\end{array}$ & Cells & Medium & Total $^{\ddagger}$ \\
\hline & cpm/mg cell protein & & \\
J774 & $2945 \pm 204^{*}$ & $7404 \pm 590$ & $265 \pm 48$ & $10614 \pm 842$ \\
$\begin{array}{l}\text { Mouse } \\
\text { peritoneal }\end{array}$ & $285 \pm 63$ & $5422 \pm 203$ & $3709 \pm 214$ & $9416 \pm 480$
\end{tabular}

Monolayers of $\mathrm{J} 774$ and mouse peritoneal macrophages (35-mm plates) were preincubated for $20 \mathrm{~h}$ in DMEM/10\% LPDS and then incubated for $8 \mathrm{~h}$ with $1.0 \mathrm{cc}$ fresh DMEM/10\% LPDS containing $\left[{ }^{3} \mathrm{H}\right.$ ]CE-labeled LDL (110 $\mu \mathrm{g}$ protein $/ \mathrm{mg}, 217 \mu \mathrm{g} \mathrm{CE} / \mathrm{ml}$; specific activity of the cholesterol moiety of the $\left[{ }^{3} \mathrm{H}\right] \mathrm{CE}-$ labeled LDL was 447 $\mathrm{cpm} / \mu \mathrm{g})$. The medium and cells were then lipid extracted and assayed for $\left[{ }^{3} \mathrm{H}\right]$ cholesterol and $\left[{ }^{3} \mathrm{H}\right] \mathrm{CE}$ content by thin-layer chromatography as described in Methods. In addition, the cells were assayed for protein content (average protein per plate: $\mathbf{0 . 6 4} \mathrm{mg}$ for $\mathrm{J} 774$ macrophages and $0.13 \mathrm{mg}$ for mouse peritoneal macrophages). $99 \%$ of the $\left[{ }^{3} \mathrm{H}\right]$ radioactivity in the labeled LDL was in CE, and this percentage did not change upon incubation of the labeled LDL in DMEM/LPDS at $37^{\circ} \mathrm{C}$ in the absence of cells. The values shown for medium free $\left[{ }^{3} \mathrm{H}\right]$ cholesterol are corrected for the small amount of free $\left[{ }^{3} \mathrm{H}\right]$ cholesterol $\left(1 \%\right.$ of $\left[{ }^{3} \mathrm{H}\right]$-radioactivity in LDL) in medium incubated in the absence of cells.

* Mean of triplicates \pm SE.

${ }^{\ddagger}$ Total $=\left[{ }^{3} \mathrm{H}\right] \mathrm{CE}$ in cells + free $\left[{ }^{3} \mathrm{H}\right]$ cholesterol in cells and medium. verting LDL-cholesterol away from the ACAT pathway. However, when mouse peritoneal macrophages were incubated with LDL in serum-free, BSA-containing medium, which diminishes LDL-cholesterol excretion to undetectable levels (see ref. 21 and verified by us), LDL-induced cholesterol esterification was increased by only 2.6 -fold (from $0.5 \pm 0.06$ to $1.3 \pm 0.02 \mathrm{nmol}$ cholesteryl $\left[{ }^{14} \mathrm{C}\right]$ oleate formed $/ \mathrm{mg}$ cell protein/ $\mathrm{h}$ in the presence of $200 \mu \mathrm{g} / \mathrm{ml} \mathrm{LDL}$; under similar conditions, cholesterol esterification in $\mathrm{J} 774$ macrophges was $7.6 \pm 0.26 \mathrm{nmol} / \mathrm{mg} / \mathrm{h}$ ). Thus, even in the absence of LDL cholesterol excretion by mouse peritoneal macrophages, cholesterol esterification in response to LDL is six-fold less than that in $\mathbf{J 7 7 4}$ macrophges, indicating that the difference in cholesterol excretion in the two cell types accounts for only a minor part of the difference in cholesterol esterification.

Microsomal ACAT activity in $J 774$ and mouse peritoneal macrophages. To determine if differences in microsomal ACAT activity in $\mathrm{J} 774$ and mouse peritoneal macrophages paralleled the differences seen in these two cell types in whole cell cholesterol esterification, microsomes were prepared from J774 and mouse peritoneal macrophages that had been incubated in the absence or presence of LDL. The microsomes were then incubated with $\left[{ }^{14} \mathrm{C}\right]$ oleoyl-CoA and assayed for cholesteryl $\left[{ }^{14} \mathrm{C}\right]$ oleate formation (Table III). As was the case with whole cell cholesterol esterification (Fig. 4), ACAT activity in microsomes from both LPDS and LDL-treated J774 macrophages was greater than that in microsomes from similarly treated mouse peritoneal macrophages. This was not due to selective loss of mouse peritoneal macrophage enzymatic activity during the microsome isolation procedure, since recovery of the activity in the microsomes compared with that originally in the postnuclear supernate was $99 \%$ in mouse peritoneal macrophages and $75 \%$ in J774 macrophages; both cell types contained essentially no ACAT activity in the $100,000 \mathrm{~g}$ supernate. When the incubations were carried out in the presence of saturating amounts of exogenous cholesterol/phosphatidylcholine liposomes, even greater

Table III. Microsomal ACAT Activity in J774 and Mouse Peritoneal Macrophages Incubated in the Absence and Presence of $L D L$

\begin{tabular}{lllr}
\hline & & \multicolumn{2}{l}{ Microsomal ACAT activity } \\
\cline { 3 - 4 } Macrophage & 5-h cell & - cholesterol & + cholesterol \\
\hline & & $n m o l / m g / 15 \mathrm{~min}$ & \\
J774 & LPDS & $2.55^{\ddagger}$ & 9.32 \\
& LDL & 5.15 & 12.44 \\
MPMp* & LPDS & 0.15 & 0.34 \\
& LDL & 0.42 & 0.65 \\
\hline
\end{tabular}

Monolayers of $\mathrm{J} 774$ and mouse peritoneal macrophages (preincubated with DMEM/10\% LPDS for $20 \mathrm{~h}$ ) were incubated with DMEM/LPDS alone or containing $200 \mu \mathrm{g} / \mathrm{ml} \mathrm{LDL}$ for $5 \mathrm{~h}$. Microsomes were then prepared from these cells and assayed for ACAT activity in the absence or presence of cholesterol/phosphatidylcholine liposomes (1:1 molar ratio; $200 \mu \mathrm{g}$ cholesterol/assay) as described in Methods. The amount of microsomal protein assayed $(50 \mu \mathrm{g})$ and the time of the incubation (15 $\mathrm{min}$ ) were within the linear range of the reaction. Saturating amounts of the substrates $\left[{ }^{14} \mathrm{C}\right]$ oleoyl-CoA $(100 \mu \mathrm{M})$ and cholesterol $(200 \mu \mathrm{g})$ were utilized in the assay where indicated.

* Mouse peritoneal macrophages.

‡ Average of duplicates that varied by $<10 \%$. 
differences in microsomal ACAT activity between $\mathrm{J774}$ and mouse peritoneal macrophages were found. Thus, whether comparing ACAT activity in microsomes from LPDS vs. LDLtreated cells or in the absence or presence of exogenous cholesterol added to the ACAT assay itself, ACAT activity in J774 microsomes is markedly greater than that in mouse peritoneal microsomes.

Cholesterol esterification in acetyl-LDL-treated J774 and mouse peritoneal macrophages. The above data could be consistent with an overall deficiency in the amount of ACAT in mouse peritoneal macrophages in comparison with J774 macrophages. However, other investigators have found that acetylLDL, which delivers lipoprotein cholesterol to macrophages by a receptor (the scavenger receptor) other than the LDL receptor, markedly stimulates cholesterol esterification in mouse peritoneal macrophages (4). Therefore, we directly compared the ability of acetyl-LDL to stimulate cholesterol esterification in LPDSpreincubated $\mathrm{J} 774$ and mouse peritoneal macrophages both as a function of acetyl-LDL concentration (Fig. $6 \mathrm{~A}$ ) and time of acetyl-LDL incubation (Fig. $6 \mathrm{~B}$ ). In sharp contrast to the results with LDL, acetyl-LDL stimulates high levels of cholesterol esterification in mouse peritoneal macrophages as well as $\mathbf{J 7 7 4}$ macrophages. The data in Table IV more precisely relate cholesterol esterification to the amount of LDL or acetyl-LDL degraded in the two cell types. When the two macrophages were matched for similar amounts of total lipoprotein degradation at two different levels $(\sim 4.8$ and $9.6 \mu \mathrm{g}$ protein degraded $/ \mathrm{mg}$ cell protein $/ 5 \mathrm{~h}$ ), there is a marked deficiency of cholesterol esterification in LDL-treated mouse peritoneal macrophages in comparison with either acetyl-LDL treated mouse peritoneal macrophages or LDL-treated or acetyl-LDL-treated J774 macrophages. Note in Table IV that at lower lipoprotein concentrations, specific ${ }^{125} \mathrm{I}-\mathrm{LDL}$ degradation is also matched. At the higher lipoprotein concentrations, specific degradation ${ }^{2}$ was approximately two-fold greater in acetyl-LDL-treated macrophages than in LDL-treated macrophages, but this difference was not enough in the case of the mouse peritoneal macrophage to explain the 12-fold greater ACAT activity in acetyl-LDL-
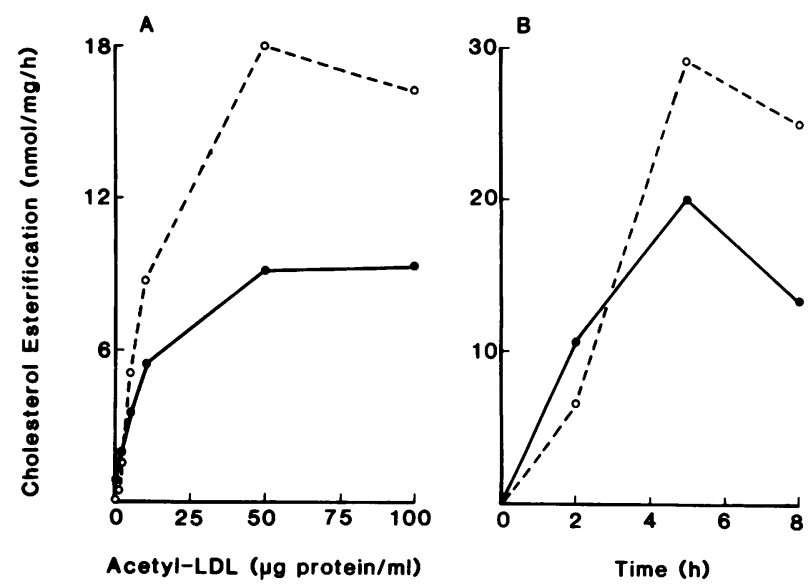

Figure 6. Concentration and time dependence of cholesterol esterification by LPDS-preincubated J774 and mouse peritoneal macrophages in the presence of acetyl-LDL. LPDS-preincubated J774 macrophages (solid circle) and mouse peritoneal macrophages (open circle) were incubated for $7 \mathrm{~h}$ with the indicated concentrations of acetyl-LDL $(A)$ or with $117 \mu \mathrm{g} / \mathrm{ml}$ acetyl-LDL for the indicated times $(B)$ and assayed for cholesterol esterification exactly as described in the legend to Fig. 4.
Table IV. Comparison of the Stimulation

of Cholesterol Esterification by LDL and Acetyl-

LDL in J774 and Mouse Peritoneal Macrophages

\begin{tabular}{|c|c|c|c|c|}
\hline \multirow[b]{2}{*}{ Macrophage } & \multirow[b]{2}{*}{ Lipoprotein } & \multicolumn{2}{|c|}{$\begin{array}{l}\text { 125I-lipoprotein } \\
\text { degradation }\end{array}$} & \multirow{2}{*}{$\begin{array}{l}\text { Cholesterol } \\
\text { esterification }\end{array}$} \\
\hline & & Total & Specific & \\
\hline & & \multicolumn{2}{|c|}{$\mu g / m g$ cell protein } & $\begin{array}{l}\text { nmol/mg cell } \\
\text { protein/h }\end{array}$ \\
\hline \multirow[t]{2}{*}{ J774 } & $\operatorname{LDL}(100)^{\ddagger}$ & $4.7^{8}$ & $3.8^{8}$ & $5.43 \pm 0.55^{\prime \prime}$ \\
\hline & acetyl-LDL (10) & 5.4 & 4.3 & $5.46 \pm 0.47$ \\
\hline \multirow[t]{2}{*}{ MPMp* } & LDL (50) & 4.2 & 3.0 & $0.14 \pm 0.02$ \\
\hline & acetyl-LDL (2) & 4.8 & 3.3 & $1.57 \pm 0.02$ \\
\hline \multirow[t]{2}{*}{ J774 } & LDL (600) & 9.9 & 4.0 & $8.03 \pm 0.15$ \\
\hline & acetyl-LDL (25) & 9.2 & 7.0 & $6.84 \pm 0.42$ \\
\hline \multirow[t]{2}{*}{ MPMp } & LDL (200) & 9.4 & 4.2 & $0.41 \pm 0.02$ \\
\hline & acetyl-LDL (5) & 9.8 & 8.9 & $5.12 \pm 0.20$ \\
\hline
\end{tabular}

Monolayers of J774 and mouse peritoneal macrophages (preincubated with DMEM/10\% LPDS for $20 \mathrm{~h}$ ) were incubated with DMEM/LPDS containing the indicated concentrations of ${ }^{125} \mathrm{I}-\mathrm{LDL}$ or ${ }^{125} \mathrm{I}$-acetylLDL for $5 \mathrm{~h}$ and assayed for total and specific ${ }^{2}$ lipoprotein degradation. Parallel dishes of the two LPDS-preincubated macrophages were incubated with DMEM/LPDS containing the indicated concentrations of unlabeled LDL or acetyl-LDL for $5 \mathrm{~h}$, pulsed with $\left[{ }^{14} \mathrm{C}\right]$ oleate for $2 \mathrm{~h}$, and then assayed for cholesterol $\left[{ }^{14} \mathrm{C}\right]$ oleate as described in Methods.

* Mouse peritoneal macrophage.

${ }^{\ddagger}$ Number in parentheses is lipoprotein concentration in $\mu \mathrm{g}$ protein/ ml.

${ }^{8}$ Average of duplicates that varied by $<10 \%$.

"Mean of triplicates \pm SE.

treated cells. Thus, despite relatively low levels of both whole cell and microsomal ACAT activity in LPDS and LDL-treated mouse peritoneal macrophages, whole-cell ACAT activity in acetyl-LDL-treated mouse peritoneal macrophages is very high.

We next examined ACAT activity in microsomes from acetyl-LDL-treated mouse peritoneal macrophages. The cells were incubated for $5 \mathrm{~h}$ with $50 \mu \mathrm{g} / \mathrm{ml}$ acetyl-LDL, and microsomes isolated from these cells were assayed for ACAT activity, which was 1.78 and $2.49 \mathrm{nmol} / \mathrm{mg} / 15 \mathrm{~min}$ in the absence and presence of exogenous cholesterol liposomes ( $200 \mu \mathrm{g}$ cholesterol/assay), respectively. Thus, although microsomal ACAT activity in acetyl-LDL-treated mouse peritoneal macrophages was substantially higher (approximately four-fold) than that in LDL-treated mouse peritoneal macrophages (see Table III), the increase was much less than that seen in the whole cell ACAT assay $(\sim 40$ fold increase in acetyl-LDL vs. LDL-treated cells; see Figs. 4 and 6). In contrast, microsomal ACAT activity in acetyl-LDLtreated $\mathrm{J} 774$ macrophages -4.24 and $9.98 \mathrm{nmol} / \mathrm{mg} / 15 \mathrm{~min}$ in the absence and presence of cholesterol, respectively-was similar to that in LDL-treated J774 macrophages (see Table III). This similarity was also seen in whole-cell ACAT activity in LDL and acetyl-LDL-treated J774 macrophages (see Figs. 4 and 6).

Down-regulation of the $L D L$ receptor in mouse peritoneal and J774 macrophages. The marked stimulation of cholesterol esterification by LDL in $\mathbf{J 7 7 4}$ macrophages is clearly an important property related to the ability of these cells to accumulate $\mathrm{CE}$ in the presence of LDL. Another important characteristic 
of the $\mathbf{J 7 7 4}$ macrophage that contributes to its ability to accumulate LDL-CE is the diminished down-regulation of its LDL receptor and $\mathrm{HMG}-\mathrm{CoA}$ reductase (8), and we have demonstrated a relationship between these two important $\mathrm{J} 774$ macrophage properties by showing that inhibition of cholesterol esterification leads to increased receptor and reductase down-regulation (9). We theorized that, in the basal state, J774 macrophages divert LDL cholesterol away from its down-regulatory function into the ACAT pathway and that this diversion is prevented by ACAT inhibition (9). To further test this relationship, we determined the degree of LDL receptor down-regulation in mouse peritoneal macrophages, cells which in the basal state have very low levels of LDL-induced cholesterol esterification and thus would not be expected to divert regulatory cholesterol. Cells were incubated for $14 \mathrm{~h}$ in LPDS-containing medium alone or in the presence of increasing amounts of LDL and then assayed for specific ${ }^{125} \mathrm{I}-\mathrm{LDL}$ degradation (Fig. 7). At each preincubation LDL concentration, the mouse peritoneal macrophage receptor is substantially more down-regulated than the $\mathbf{J} 774$ receptor. For example, after incubation with $50 \mu \mathrm{g} / \mathrm{ml}$ LDL, mouse peritoneal macrophage receptor activity is downregulated by $55 \%$ whereas the $\mathrm{J} 774$ receptor is down-regulated by only $34 \%$. Furthermore, when the cells were preincubated with $50 \mu \mathrm{g} / \mathrm{ml} \mathrm{LDL}$ in the presence of the ACAT inhibitor 58$035(5 \mu \mathrm{g} / \mathrm{ml}), \mathrm{J} 774$ receptor down-regulation increased to a level $(62 \%)$ similar to that in the mouse peritoneal macrophage, whereas mouse peritoneal macrophage receptor down-regulation was little changed $(58 \%)$ by ACAT inhibition. In a related experiment, the LDL receptor of mouse peritoneal macrophages was first up-regulated by an initial incubation with LPDS alone and then subjected to a second incubation with LDL $\pm 58-035$, and similar results were obtained: $61 \%$ down-regulation by LDL and $60 \%$ down-regulation by LDL $+58-035$. Thus, in mouse peritoneal macrophages, as in ACAT-inhibited J774 macrophages, LDL-derived cholesterol is a relatively poor substrate for cholesterol esterification and a relatively effective mediator of LDL receptor down-regulation.

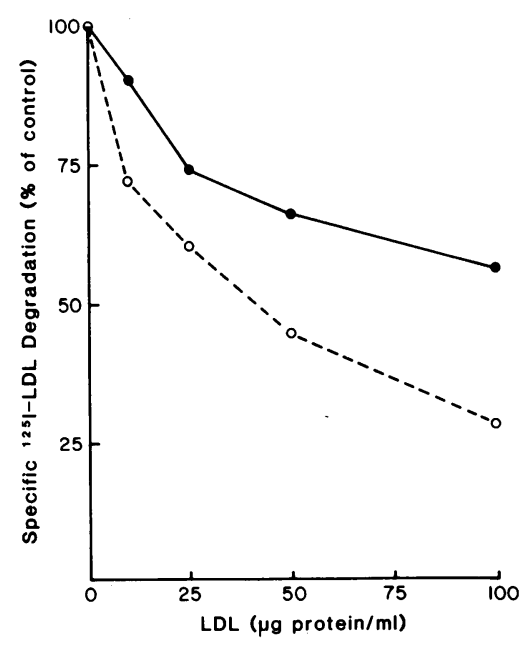

Figure 7. LDL-mediated down-regulation of LDL receptor activity in $\mathrm{J} 774$ and mouse peritoneal macrophages. J774 macrophages (solid circle) and mouse peritoneal macrophages (open circle) were preincubated for $14 \mathrm{~h}$ in DMEM/10\% LPDS alone or containing the indicated concentrations of LDL. The cells were then washed with warm PBS and subjected to a 5-h incubation with DMEM/ $0.1 \%$ BSA containing 5 $\mu \mathrm{g} / \mathrm{ml}{ }^{125} \mathrm{I}-\mathrm{LDL} \pm 500$ $\mu \mathrm{g} / \mathrm{ml}$ unlabeled LDL. The cells were then assayed for specific ${ }^{125} \mathrm{I}-$ LDL degradation as described in Methods; the duplicate values obtained at each LDL concentration varied by $<5 \%$. The data are expressed as the percentage of control value, the specific ${ }^{125} \mathrm{I}-\mathrm{LDL}$ degradation in cells preincubated in DMEM/LPDS alone. The control values were 0.9 and $0.7 \mu \mathrm{g}{ }^{125} \mathrm{I}-\mathrm{LDL}$ degraded/mg cell protein for $\mathrm{J774}$ and mouse peritoneal macrophages, respectively.

\section{Discussion}

We have demonstrated that foam cell-forming J774 macrophages metabolize intracellular cholesterol in a markedly different fashion from mouse peritoneal macrophages, which do not form foam cells in the presence of LDL. Whereas the two murine macrophages display similar degrees of chloroquine-inhibitable ${ }^{125}$ I-LDL degradation (Fig. 2) and LDL-CE hydrolysis (Table II), indicating similar delivery of LDL-cholesterol to lysosomes, whole cell cholesterol esterification (Fig. 4) and microsomal ACAT (Table III) in LDL-treated J774 and mouse peritoneal macrophages differs markedly. In addition, there is also a difference in the ability of LDL to down-regulate LDL receptor activity in the two cells (Fig. 7). Thus, in J774 macrophages, as opposed to mouse peritoneal macrophages, LDL cholesterol is markedly more effective at stimulating cholesterol esterification and less effective at causing receptor down-regulation, two properties which help to explain the ability of $\mathrm{J774}$ macrophages to accumulate LDL-derived CE. Conversely, the contrasting fates of LDL-cholesterol in mouse peritoneal macrophages (decreased esterification and increased down-regulation) help to explain the inability of these cells to form foam cells in the presence of LDL. The failure of mouse peritoneal macrophages to accumulate $\mathrm{CE}$ from $\mathrm{LDL}$ is clearly not due to a simple lack of LDL receptor activity.

We found that $\mathrm{J} 774$ macrophages incubated in the absence of lipoproteins have greater whole-cell ACAT activity than similarly treated mouse peritoneal macrophages (Fig. 4). We also found that isolated microsomes from $\mathrm{J} 774$ macrophages demonstrate much greater ACAT activity than microsomes from mouse peritoneal macrophages even when assayed in the presence of saturating amounts of exogenous cholesterol (see Table III). These data may suggest that $\mathrm{J} 774$ macrophages have a greater amount of the ACAT enzyme. However, it is also possible that neither the whole cell ACAT assay in cells incubated in the absence of lipoproteins nor the microsomal ACAT assay in the presence of cholesterol liposomes is a reliable indicator of the amount of ACAT in cells. For instance, the former finding may indicate that J774 ACAT is better-able to be stimulated by endogenous cellular cholesterol than mouse peritoneal macrophage ACAT. The latter finding may imply that the J774 enzyme is simply more stable in a broken cell preparation or that cholesterol/phosphatidylcholine liposomes are a relatively poor cholesterol donor for the mouse peritoneal macrophage enzyme. The finding that acetyl-LDL can markedly stimulate whole-cell ACAT activity in mouse peritoneal macrophages (to levels even greater than those in similarly treated $\mathbf{J 7 7 4}$ macrophages; see Fig. 6) indicates that under the proper conditions, perhaps related to the route of lipoprotein-cholesterol delivery to the cell, mouse peritoneal macrophage ACAT can be markedly stimulated. If in fact these cells do have less ACAT, this deficiency can be compensated for by maximal stimulation by acetyl-LDL. Interestingly, the ratio of microsomal ACAT activity from acetylLDL vs. LDL-treated mouse peritoneal macrophages $(\sim 4: 1)$ was much less than the ratio of whole-cell ACAT activity in acetyl-LDL vs. LDL-treated mouse peritoneal macrophages ( 40:1). This may indicate that either microsomal ACAT from acetyl-LDL-treated cells is relatively unstable or that the acetylLDL effect involves processes requiring the intact cell for full expression, such as intracellular cholesterol transport.

Along these lines, we considered the possibility that the difference in LDL vs. acetyl-LDL-induced cholesterol esterification 
in mouse peritoneal macrophages as well as the difference in LDL-induced cholesterol esterification in $\mathrm{J} 774$ vs. mouse peritoneal macrophages might be due to differences in the kinetics of lipoprotein entry into and degradation by the cells. However, this idea is not supported by ${ }^{125} \mathrm{I}$-lipoprotein degradation time course data that show that ${ }^{125} \mathrm{I}$-LDL degradation and ${ }^{125} \mathrm{I}$--acetylLDL degradation follow similar time courses in mouse peritoneal macrophages (not shown). Similarly, ${ }^{125} \mathrm{I}-\mathrm{LDL}$ degradation follows a similar time course in $\mathrm{J} 774$ macrophages and mouse peritoneal macrophages (Fig. $2 \mathrm{~B}$ ).

Another possibility is related to the observation in other cells that the general mechanism of lipoprotein-induced stimulation of ACAT is related to substrate (i.e., lipoprotein-derived cholesterol) activation $(22,23)$ and perhaps cholesterol-induced allosteric activation (22). Thus, one possible interpretation of our data is that $\mathbf{J 7 7 4}$ and mouse peritoneal macrophages differ in their ability to transfer LDL-derived cholesterol, but not acetylLDL-derived cholesterol, to microsomal ACAT. Perhaps LDL and acetyl-LDL, which enter the cell by two distinct receptors (4), are routed to two different subpopulations of lysosomes (see refs. 24-26 for examples of lysosomal subpopulations) that differ in their ability to transfer cholesterol to microsomal ACAT in the mouse peritoneal macrophage but not in the J774 macrophage. This hypothesis implies that the information directing the ligands to different lysosomal pathways initially resides in the ligand-receptor complex.

The demonstration that $\mathbf{J} 774$ macrophages and mouse peritoneal macrophages degrade similar amounts of LDL was necessary to allow us to subsequently compare intracellular lipoprotein-cholesterol metabolism in these two murine macrophages. Freshly isolated mouse peritoneal macrophages have been previously demonstrated to display very low LDL receptor activity $(5,11)$, and thus their inability to accumulate LDLderived $\mathrm{CE}$ was thought to be explainable by this finding. However, Mahley et al. (27) have stated that mouse peritoneal macrophage LDL receptors can be up-regulated to a certain degree, and Hammond et al. (6), using the immunoblot technique with antibodies to the adrenal LDL receptor, have recently demonstrated that mouse peritoneal macrophages possess high levels of the apo B,E receptor. These data, together with our data showing significant ${ }^{125} \mathrm{I}-\mathrm{LDL}$ degradation by cells that had been preincubated in LPDS-containing medium (Fig. 1), indicate that the inability of these cells to accumulate LDL-derived CE is not simply due to a lack of LDL receptors or LDL receptor activity. In this respect, mouse peritoneal macrophages are similar to human monocyte-derived macrophages, which also demonstrate significant LDL receptor activity and yet do not accumulate LDL-derived CE $(28,29)$. In fact, we have found that despite the relatively high level of ${ }^{125} \mathrm{I}-\mathrm{LDL}$ degradation by human monocyte-derived macrophages, cholesterol esterification in these cells is stimulated very poorly by LDL (at $200 \mu \mathrm{g} / \mathrm{ml} \mathrm{LDL}$, cholesterol esterification was $0.56 \mathrm{nmol} / \mathrm{mg} / \mathrm{h}$ ) compared to LDL stimulation of cholesterol esterification in J774 cells $(7.56 \mathrm{nmol} /$ $\mathrm{mg} / \mathrm{h}$; see Fig. 4). Thus the inability of internalized LDL cholesterol to stimulate cholesterol esterification described in this report for mouse peritoneal macrophages is also found in macrophages derived by tissue culture of human blood monocytes.

Our current findings together with those in our previous reports $(8,9)$ have helped define the mechanisms whereby J774 macrophages accumulate $\mathrm{CE}$ from $\mathrm{LDL}$. The cells poorly downregulate their LDL receptors and HMG-CoA reductase (8), thus leading to increased cholesterol entry into the cell and synthesis by the cell, and they very efficiently esterify LDL-derived cholesterol (and also, perhaps, endogenous cholesterol). Furthermore, we have demonstrated that ACAT inhibition increases receptor and reductase down-regulation and have suggested that overactive cholesterol esterification by ACAT leads to diversion of LDL-cholesterol away from its regulatory functions (9). The present report confirms that a high level of ACAT activity is a prominent feature of the $\mathrm{J} 774$ macrophage. In addition, J774 macrophages have a relative deficiency in lipoprotein-derived cholesterol excretion in response to LPDS (Table I). Whether this is a primary characteristic of these cells or secondary to diversion of LDL-cholesterol by overactive ACAT (or possibly secondary to underactive $\mathrm{CE}$ hydrolysis) has yet to be determined. These important properties of $\mathrm{J} 774$ macrophages that lead to their ability to accumulate LDL-derived CE are not simply due to the fact that these macrophages are a continuous cell line, because two other macrophage cell lines-the murine P388D1 line and the human HL60 line-do not accumulate LDL-derived CE (8). Whether or not one or all of the J774 properties can be experimentally induced in macrophage models that do not form foam cells with LDL (e.g., the mouse peritoneal macrophage or the human monocyte-derived macrophage) and whether or not actual atheroma foam cells possess these properties is yet to be determined.

\section{Acknowledgments}

This work was supported in part by National Institutes of Health grants HL-22682 and 21006. Dr. Tabas is a recipient of a research award from the Pfizer Scholars Program for New Faculty.

\section{References}

1. Schaffner, T., K. Taylor, E. J. Bantucci, K. Fischer-Dzoga, J. H. Beeson, S. Glagov, and R. Wissler. 1980. Arterial form cells with distinctive immunomorphologic and histochemical features of macrophages. Am. J. Pathol. 100:57-80.

2. Gerrity, R. G. 1981. The role of the monocyte in atherogenesis. I. Transition of blood-borne monocytes into foam cells in fatty lesions. Am. J. Pathol. 103:181-190.

3. Faggiotto, A., R. Ross, and L. Harker. 1984. Studies of hypercholesterolemia in the nonhuman primate. I. Changes that lead to fatty streak formation. Artheriosclerosis. 4:323-340.

4. Brown, M. S., and J. L. Goldstein. 1983. Lipoprotein metabolism in the macrophage: Implications for cholesterol deposition in atherosclerosis. Annu. Rev. Biochem. 52:223-261.

5. Brown, M. S., S. K. Basu, J. R. Falck, Y. K. Ho, and J. L. Goldstein. 1980. The scavenger cell pathway for lipoprotein degreadation: specificity of the binding site that mediates the uptake of negatively charged LDL by macrophages. J. Supramol. Struct. 13:67-81.

6. Hammond, M. E., C. Koo, R. W. Mahley, and T. L. Innerarity. 1985. Characterization of mouse peritoneal macrophage receptors for $\beta$-VLDL. Artheriosclerosis. 5:506a. (Abstr.)

7. Goldstein, J. L., and M. S. Brown. 1977. The low-density lipoprotein pathway and its relation to atherosclerosis. Annu. Rev. Biochem. 46:897-930

8. Tabas, I., D. A. Weiland, and A. R. Tall. 1985. Unmodified low density lipoprotein causes cholesteryl ester accumulation in $\mathbf{J} 774$ macrophages. Proc. Natl. Acad. Sci. USA. 82:416-420.

9. Tabas, I., D. A. Weiland, and A. R. Tall. 1986. Inhibition of acyl coenzyme A:cholesterol ester transferase in $\mathrm{J} 774$ macrophages enhances down-regulation of the low density lipoprotein receptor and 3-hydroxy3-methylglutaryl coenzyme A reductase and prevents low density lipoprotein-induced cholesterol accumulation. J. Biol. Chem. 261:3147-3155. 
10. Edelson, P. J., and Z. A. Cohn. 1976. Purification and cultivation of monocytes and macrophages. In In Vitro Methods in Cell-mediated and Tumor Immunity. B. R. Bloom and J. R. David, editors. Academic Press, New York. 333-340.

11. Goldstein, J. L., Y. K. Ho, S. K. Basu, and M. S. Brown. 1979. A binding site on macrophages that mediates uptake and degradation of acetylated low density lipoprotein producing massive cholesterol deposition. Proc. Natl. Acad. Sci. USA. 76:333-337.

12. Goldstein, J. L., S. K. Basu, and M. S. Brown. 1983. Receptormediated endocytosis of low-density lipoprotein in culture cells. Methods Enzymol. 98:241-260.

13. Tall, A., D. Sammett, and E. Granot. 1986. Mechanisms of enhanced cholesteryl ester transfer from high density lipoproteins to apolipoprotein B-containing lipoproteins during alimentary lipemia. J. Clin. Invest. 77:1163-1172.

14. Tall, A. R., D. Sammett, G. M. Vita, R. Deckelbaum, and T. Olivecrona. 1984. Lipoprotein lipase enhances the cholesteryl ester transfer protein-mediated transfer of cholesteryl esters from high density lipoproteins to very low density lipoproteins. J. Biol. Chem. 259:95879594.

15. Lowry, O. H., N. J. Rosenbrough, A. L. Farr, and R. J. Randall. 1951. Protein measurement with the folin reagent. J. Biol. Chem. 193: 265-275.

16. Folch, J., I. Ascoli, M. Lees, J. A. Meath, and F. N. LeBaron. 1951. Preparation of lipid extracts from brain tissue. J. Biol. Chem. 191: 833-841.

17. Bligh, E. G., and W. J. Dyer. 1959. A rapid method for total lipid extraction and purification. Can. J. Biochem. Physiol. 37:911-917.

18. Bartlett, G. R. 1959. Phosphorous assay in column chromatography. J. Biol. Chem. 234:466-468.

19. Brown, M. S., S. E. Dana, and J. L. Goldstein. 1975. Cholesterol ester formation in cultured human fibroblasts. J. Biol. Chem. 250:40254027.

20. Steinbrecher, U. P., S. Parthasarathy, D. S. Leake, J. L. Witztum, and D. Steinberg. 1984. Modification of low density lipoprotein by en- dothelial cells involves lipid peroxidation and degradation of low density lipoprotein phospholipids. Proc. Natl. Acad. Sci. USA. 81:3883-3887.

21. Ho, Y. K., M. S. Brown, and J. L. Goldstein. 1980. Hydrolysis and excretion of cytoplasmic cholesteryl esters by macrophages: stimulation by high density lipoprotein and other agents. J. Lipid Res. 21: 391-398.

22. Hashimoto, S., C. A. Drevon, D. B. Weinstein, J. S. Bernett, S. Dayton, and D. Steinberg. 1983. Activity of acyl-CoA:cholesterol acyltransferase and 3-hydroxy-3-methylglutaryl reductase in subfractions of hepatic microsomes enriched with cholesterol. Biochim. Biophys. Acta. 754:126-133.

23. Synouri-Vrettakou, S., and K. A. Mitropoulos. 1983. Acyl-coenzyme A:cholesterol acyltransferase. Transfer of cholesterol to its substrate pool and modulation of activity. Eur. J. Biochem. 133:299-307.

24. Rome, L. H., A. J. Garvin, M. M. Allietta, and E. F. Neufeld. 1979. Two species of lysosomal organelles in cultured human fibroblasts. Cell. 17:143-153.

25. Diment, S., and P. Stahl. 1985. Macrophage endosomes contain proteases which degrade endocytosed protein ligands. J. Biol. Chem. 260:15311-15317.

26. Oliver, C. 1980. Cytochemical localization of acid phosphatase and trimetaphosphatase activities in exocrine acinar cells. J. Histochem. Cytochem. 28:78-81.

27. Mahley, R. W., T. L. Innerarity, M. S. Brown, Y. K. Ho, and J. L. Goldstein. 1980. Cholesteryl ester synthesis in macrophages: stimulation by $\beta$-very low density lipoproteins from cholesterol-fed animals of several species. J. Lipid Res. 21:970-980.

28. Shechter, I., A. M. Fogelman, M. E. Haberland, J. Seager, M. Hokom, and P. A. Edwards. 1981. The metabolism of native and malondialdehyde-altered low density lipoproteins by human monocytemacrophages. J. Lipid Res. 22:63-71.

29. Traber, M. G., and H. J. Kayden. 1980. Low density lipoprotein receptor activity in human monocyte-derived macrophages and its relation to atheromatous lesions. Proc. Natl. Acad. Sci. USA. 77:54665470 . 